Efeitos de óleos essenciais de plantas no tempo de sono induzido por cetamina em camundongos

\section{Simony Fauth ${ }^{1 *}$; Adriana Rolim Campos ${ }^{1}$; Edilberto Rocha Silveira ${ }^{2}$; Vietla Satyanarayana Rao'}

${ }^{1}$ Departamento de Fisiologia e Farmacologia, Faculdade de Medicina, Universidade Federal do Ceará, CP 3157, 60430-

270, Fortaleza, CE

2 Departamento de Química Orgânica e Inorgânica, Centro de Ciências, Universidade Federal do Ceará, Fortaleza, CE, Brasil sfauth@uol.com.br

\section{Resumo}

Estudos anteriores mostraram que óleos essenciais voláteis obtidos de plantas potenciam o tempo de sono induzido por pentobarbital e álcool em camundongos. Cetamina é um anestésico muito utilizado em crianças, sendo conhecida por causar uma anestesia dissociativa. Seus efeitos alucinógenos podem ser reduzidos quando administrada em associação a benzodiazepínicos. O objetivo deste estudo foi determinar a influência dos óleos de Psidium guyanensis (Araçá azedo), Psidium pohlianum (Araçá doce), Psidium guajava (Araçá goiaba), Rosmarinus officinalis (Alecrim) e Lippia alba (Cidreira) no tempo de sono induzido por cetamina em camundongos. Os resultados indicam que o tempo de sono induzido por cetamina foi prolongado pelos óleos essenciais de Psidium guyanensis, Psidium pohlianum, Psidium guajava e Lippia Alba mostrando novas possibilidades de associação com a cetamina a fim de prolongar o seu efeito sedativo, proporcionando uma anestesia mais adequada.

Cetamina é uma droga que possui propriedades especiais que fazem dela o único agente que serve como anestésico, sedativo, amnésico e analgésico, a anestesia dissociativa causada pela cetamina pode ser revertida por propofol e midazolam ${ }^{7}$. Santos et al. ${ }^{8}$ mostrou potenciação do tempo de sono induzido por pentobarbital utilizando os óleos essenciais das folhas de Psidium guyanensis (Araçá azedo) e Psidium pohlianum (Araçá doce). As folhas de Psidium guajava (Araçá goiaba) são utilizadas na forma de chá e possuem também propriedades antimicrobianas, anidiarréica e narcótica ${ }^{5,4}$. Rosmarinus officinalis (Alecrim) e seus constituintes, principalmente o ácido caféico e derivados (ácido rosmarínico) possuem potencial terapêutico no tratamento da asma brônquica, desordens espasmogênicas, úlcera péptica, doenças inflamatórias, hepatotoxicidade, aterosclerose, doença cardíaca isquêmica, catarata, câncer e baixa mobilidade espermática ${ }^{1}$. Lipia alba é popularmente conhecida como cidreira. O chá de suas folhas é utilizado como calmante, antiespasmódico e em distúrbios gastrintestinais. Os óleos essenciais de cidreira aumentam a latência de convulsão em relação ao controle, assim como a percentagem de sobrevivência dos animais, além de apresentar efeito anticonvulsivante nas doses de 200 e 400 mg/ kg v.o. ${ }^{2}$.

Este trabalho mostra que a administração intraperitoneal de $150 \mathrm{mg} / \mathrm{kg}$ de cetamina produziu um tempo de sono de 36,61 $\pm 1,71$ min. O pré-tratamento com o óleo essencial de Araçá doce, Araçá goiaba e Cidreira (200 e 400 mg/kg) e Araçá azedo $(400 \mathrm{mg} / \mathrm{kg})$ produziu significativa potenciação do tempo de sono induzido pela cetamina em camundongos. $\mathrm{O}$ óleo essencial de Alecrim em nenhuma das doses produziu potenciação do tempo de sono. Os óleos essenciais nas doses utilizadas (200 e $400 \mathrm{mg} / \mathrm{kg}$ ) não apresentaram efeitos per si.

Nossos resultados indicam que o prolongamento do tempo de sono, induzido por cetamina, pelos óleos essenciais pode ser mediado pela inibição da metabolização das enzimas $\mathrm{P} 450^{9}$ ou pela própria ação no Sistema Nervoso Central. Estudos anteriores estabeleceram que os óleos essenciais potenciam o tempo de sono induzido por pentobarbital ${ }^{9}$ e possuem efeito anticonvulsivante ${ }^{2,3,8,11}$. Estes efeitos são provavelmente devido a presença de terpenos nos óleos. O tempo de sono induzido pela cetamina potenciado pelos óleos essenciais pode ter vantagens, já que pode permitir a diminuição da dose de cetamina e, conseqüentemente, seus efeitos colaterais. Além do mais, estes óleos essenciais podem também potenciar a inibição da sensibilização central induzida por cetamina no sistema nociceptivo ${ }^{6}$ e, portanto, produzir um potente efeito analgésico.

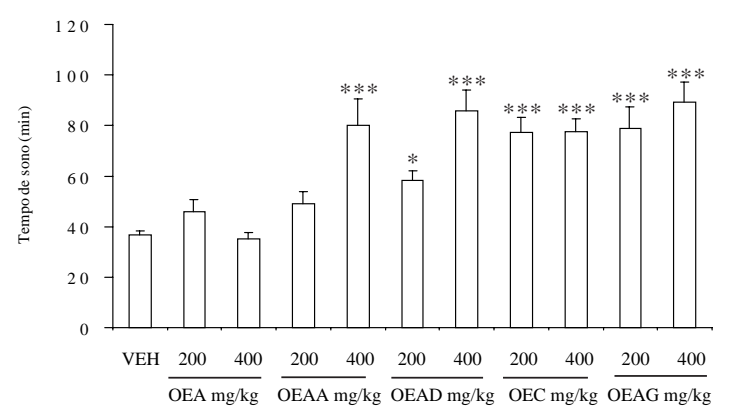

Figura 1. Efeito dos óleos essenciais de Alecrim (OEA), Araçá azedo (OEAA), Araçá doce (OEAD), Cidreira (OEC), Araçá goiaba (OEAG) e Veículo (VEH) no tempo de sono induzido por cetamina em camundongos. Os animais $(n=6)$ foram tratados oralmente com veículo (Controle Normal, $10 \mathrm{ml} / \mathrm{kg}$ ), OEA, OEAA, OEAD, OEC e OEAG (200 e $400 \mathrm{mg} / \mathrm{kg}), 1 \mathrm{~h}$ antes da administração de cetamina (150 mg/kg; i.p.). Os dados estão apresentados como média \pm SEM. $* \mathrm{p}<0,05$ e **p<0,001 comparado ao grupo veículo (ANOVA e seguida de Teste Student-Newman-Keul). 


\section{Material e Métodos}

Os óleos essenciais foram obtidos no Departamento de Química Orgânica e Inorgânica da Universidade Federal do Ceará e Cetamina foi obtida na sua forma comercial (Ketalar®, Parke-Davis, Brasil).

Foram utilizados camundongos albinos (Mus musculus) variedade Swiss webster, adultos do sexo feminino, pesando entre 25-30 g, provenientes do Biotério Central da Universidade Federal do Ceará, mantidos à temperatura ambiente, com ciclos de $12 \mathrm{em} 12 \mathrm{~h}$, recebendo ração padrão (Purina Chow) e livre acesso a água.No modelo do tempo de sono induzido por Cetamina $150 \mathrm{mg} / \mathrm{kg}$ os animais foram divididos em 11 grupos. O primeiro grupo (controle) foi tratado oralmente com veículo (VEH) (Tween 80 à $2 \%$ em água destilada, $10 \mathrm{ml} / \mathrm{kg}$ ). Os demais grupos foram tratados oralmente com óleos essenciais de Psidium guyanensis (OEAA), Psidium pohlianum (OEAD), Psidium guajava (OEAG), Rosmarinus officinalis (OEA) e Lippia alba (OEC), nas doses de 200 e 400 mg/lg. Uma hora depois do tratamento, o tempo de sono foi induzido pela administração intraperitoneal de cetamina $(150 \mathrm{mg} / \mathrm{kg})$. Iniciado o período de sono, os animais, em seus respectivos grupos, foram posicionados em decúbito dorsal, em local de adequada observação. Os animais foram observados durante todo o período de sono, sendo este tempo registrado em minutos, tendo como situação de retorno ao estado de alerta o momento no qual o animal alterou sua posição de decúbito.

\section{Referências}

${ }^{1}$ al-Sereiti MR . Indian J Exp Biol. 1999 Feb; 37(2):124-30

${ }^{2}$ de Barros Viana GS, do Vale TG, Silva CM, de Abreu Matos FJ. Biol Pharm Bull 2000 Nov;23(11):1314-7

${ }^{3}$ Kimura, M., Tanaka, K., Takamura, Y . Biol. Pharma. Bull 1994. 17:1232-1240

${ }^{4}$ Lozoya X, Becerril G, Martinez M. Arch Invest Med (Mex). 1990 Apr-Jun;21(2):155-62

${ }^{5}$ Lutterodt GD, Maleque A.J Ethnopharmacol. 1988 Dec;24(23):219-31

${ }^{6}$ McMohan, S., B., Lewin, J.R., Wall, P. D. Curr. Opun. Neurobiol. 19933:602-610

${ }^{7}$ Reboso Morales JA, Gonzalez Miranda F. Rev Esp Anestesiol Reanim. 1999 Mar;46(3):111-22

${ }^{8}$ Santos F A, Rao VSN. Silveira E R. Phytother. Res. 1996 10:655658

${ }^{9}$ Shen Y, Sangiah S. Vet. Hum. Toxicol. 1995 37:201-203

${ }^{10}$ Tona L, Kambu K, Ngimbi N, Mesia K, Penge O, Lusakibanza M, Cimanga K, De Bruyne T, Apers S, Totte J, Pieters L, Vlietinck AJ. Phytomedicine 2000 Mar;7(1):31-8

${ }^{11}$ Weyers W, Broadbeck R. Pharm. Unfer Zeit. 1989; 18:82-86

\section{Effect of Plantago australis leaves on} different gastric ulcer models

\section{M.E. Bürger*; P.C. Ghedini; B. Baldisserotto; N.M.S. Palmeiro; C.E. Almeida; C.F. Lenzi; A.C. Silva; C.Q. Oliveira}

Departamento de Fisiologia, Universidade Federal de Santa Maria, 97105-900, Santa Maria, RS, Brazil

mariliseeb@smail.ufsm.br

\section{Abstract}

The anti-ulcerogenic effect of the crude ethanolic extract (CEE) of Plantago australis leaves was tested against ethanol-, indomethacin-, and cold restrain-induced stress ulcers. The CEE (500 and $1000 \mathrm{mg} / \mathrm{kg}$ ) reduced the lesion index (LI) and the ulcer index in ethanol-induced ulcers, and the dose of 1000 $\mathrm{mg} / \mathrm{kg}$ increased the amount of mucous. The highest dose of the CEE reduced the LI of cold restraint-induced stress ulcers when compared to the control group. The indomethacin-induced ulcers were not affected by this extract.

The genus Plantago (Plantaginaceae) has several species with laxative, diuretic, anti-inflammatory, anti-bacterial, anti-diarrhoeic, cicatrizing, and other medicinal properties ${ }^{1}$. One of these species, Plantago australis Lam., is found in almost all Latin America and west of United States. This plant is commonly used to give medical care to throat infections, wounds, boils and varicose veins. In addition, it has been used to treat inflammations and diarrhoea ${ }^{2}$. Therefore, the aim of this study was to investigate the effect of the crude ethanolic extract (CEE) of $P$. australis leaves on different gastric ulcer models on rats.

The doses of 500 and $1000 \mathrm{mg} / \mathrm{kg}$ of the P. australis CEE reduced the lesion index (LI) of ethanol-induced ulcers in $27.65 \%(4.16 \pm 0.40)$ and $40.69 \%$ (3.41 \pm 0.35$)$, respectively, when compared with the control group (5.75 \pm 0.21$)$. These doses of the CEE also decreased in 81.3\% (12.0 \pm 2.97$)$ and 95.8\% (2.66 \pm 0.49 ), respectively, the ulcer index (UI) with relation to the control group $(64.2 \pm 5.76)$. The dose of $1000 \mathrm{mg} / \mathrm{kg}$ increased the mucous secretion (328.76 \pm 10.71$)$ with relation to control group (252.46 \pm 12.99 ), but the dose of $500 \mathrm{mg} / \mathrm{kg}$ did not change this parameter $(282,63 \pm 26,39)$. The CEE did not showed any significant effect on the determination of non-proteic sulphide groups (GSH) or on the indomethacin-induced ulcers. The highest dose of the CEE reduced the LI of cold restraint-induced stress ulcers (4.16 $\pm 0.60)$ when compared to the control group $(6.5 \pm 0.76)$.

Ethanol is highly corrosive to the rat gastric mucosa. It promotes superficial cellular necrosis and release of histamine and leucotrine $\mathrm{C} 4$. These tissue-derived mediators act on gastric microvasculature, starting events that result in mucosal and possibly submucosal tissue destruction ${ }^{3}$. The results of our 